\title{
A synopsis of problems and prospects of SADC, EAC and COMESA tripartite free trade area
}

\author{
Amos Saurombe \\ Department of Mercantile Law, \\ College of Law, \\ Universty of South Africa, \\ P.O. Box 392 Unisa, Code 0003, South Africa \\ E-mail: sauroa@unisa.ac.za
}

\begin{abstract}
On 12 June 2011, the members states of three regional economic communities (RECs) of the East Africa Community (EAC), the Common Market for East and Southern Africa (COMESA) and the Southern African Development Community (SADC) signed an agreement to negotiate the establishment of a tripartite FTA consisting of all threes RECS. The work includes reduction of tariffs and non-tariff barriers from Cape to Cairo. The cost of doing business on the continent is still a major stumbling block because of the poor status of roads, railways and communication lines. The tripartite FTA will require a harmonised legal framework that gives effect to the objectives for deeper integration in the region. This paper is an attempt to unpack the kind of challenges and proposes solutions in the negotiation and establishment of the tripartite FTA. Ultimately, the paper will demonstrate that the cost of non-integration far outweighs the cost of integration.
\end{abstract}

Keywords: tripartite FTA; regional economic community; REC; integration; harmonisation.

Reference to this paper should be made as follows: Saurombe, A. (2013) 'A synopsis of problems and prospects of SADC, EAC and COMESA tripartite free trade area', Int. J. Liability and Scientific Enquiry, Vol. 6, Nos. 1/2/3, pp.116-124.

Biographical notes: Amos Saurombe is an Associate Professor of Law at the University of South Africa (Unisa). His area of specialisation is teaching and research in international economic law, e-commerce law and intellectual property law. He has previously taught at the North West University for three years and the University of Fort Hare for two years. He completed his doctoral studies in 2011 with the North West University. He has also been a Guest Lecturer at the University of Pretoria, University of Fort Hare, North West University and University of Lusaka for the LLM Programme in International Trade and Investment Law in Africa. He is also part-time trade policy advisor for the Southern African Development Community (SADC).

\section{Introduction}

Regional integration remains a key component of development aspirations and strategies for many African countries. This has been as a result of the constant reality of Africa's marginalisation in the era of globalisation and the poor economic track record of most 
African states. This has partly paved way for regional integration in Africa. ${ }^{1}$ As a way of responding to this challenge and the desire to improve the economic fortune of Africa, there have been moves at both regional and sub regional level to join hands in harnessing the scarcely available resources with an objective of forming a formidable force that can be reckoned with. For this reason, SADC, EAC and COMESA are at the forefront of extending the boundaries of their respective FTAs to form a grand tripartite FTA whose membership includes all the members of the mentioned RECs. This is a huge adventure on the part of all members involved. Only time will tell if this dream can be realised in our lifetime. A number of challenges have already been identified. Most of these challenges are not new. The major one has long been identified by Mutharika as a need to have in place effective regional institutions and adequate institutional machinery to oversee the implementation of these development policies as an essential condition for regional integration. ${ }^{2}$ This paper will identify a number of expected challenges for the tripartite FTA and suggest ways of overcoming those challenges. In the end an emphasis on the importance of the tripartite FTA will demonstrate that the cost of non-integration far outweighs the cost of integration. The tripartite FTA will definitely add value to the existing trade regimes.

\section{Background to the tripartite FTA}

The tripartite FTA is not an attempt to merge SADC, COMESA and the EAC. It is about merging the existing FTAs in COMESA, EAC and SADC into a single wider FTA within the context of intra-regional liberalisation. ${ }^{3}$ Therefore it is not a REC negotiation process but a process driven by member states as customs territories within the RECs. ${ }^{4}$ In June 2008, the Secretaries-General of EAC, COMESA and SADC announced that they wished to see a coordinated approach between their members. ${ }^{5}$ In addition, an October 2008 Kampala, Uganda Tripartite Summit of leaders from the three groups' 26 member states announced that they wished also to work towards a free trade zone, which has long been a goal of the region as a whole, but has proved difficult to implement in the past. $^{6}$ Discussions at Secretariat level have for some years been focusing on the harmonisation and coordination of programmes and policies in areas of common interest. ${ }^{7}$ The official communiqué of the 2008 COMESA-EAC-SADC Tripartite Summit states that;

“... the FTA is a crucial building bloc towards achieving the African Economic Community as outlined by the Treaty of Abuja.",

On 12 June 2011 this tripartite summit signed an agreement to launch negotiations for the establishment of the FTA.

\section{Composition of the tripartite FTA}

The tripartite FTA will be an expanded trade bloc comprising 26 countries that make up half of the African Union (AU) membership. ${ }^{9}$ This new FTA will comprise a population of more than 600 million people and 624 billion dollars with a per capita GDP averaging 1 trillion dollars. ${ }^{10}$ 


\section{Scope of negotiations and mandate of the tripartite FTA}

The 26 countries of the tripartite FTA will need to undertake tariff negotiations with each other. Non-tariff negotiations among members of the customs unions, i.e., members of SACU and the EAC will need to negotiate as one party. It is envisaged that within a period of 24-36 months negotiations should take place. These negotiations will cover trade in goods. The specific coverages are tariff liberalisation, rules of origin, dispute resolution, customs procedures and simplification of customs documentation, transit procedures, non-tariff barriers, trade remedies, technical barriers to trade and sanitary and phyto-sanitary measures. A number of items have been listed as key issues for the technical work of the Tripartite Task Force. These include infrastructure programmes encompassing road, rail, ports, air transport, energy and ICT. These are critical areas that have already been identified in the past. The poor state of road, rail and air transport network makes trade very expensive. The focus is also on market integration that is characterised by the removal of tariff and non-tariff barriers and implementation of trade facilitation measures. The task team is also mandated to initiate a trade and transport facilitation programme. In addition the task team has to make plans for industrial developments. Over and above these activities the tripartite task team is required to draft an agreement and annexes that will guide relations in this agreement.

\section{Prospects and advantages of the tripartite FTA}

The most apparent prospect for the grand FTA is the existence of three FTAs to build upon. This tripartite FTA will facilitate the free movement of business persons, the joint implementation of inter-regional infrastructure programmes, as well as institutional arrangements on the basis of which the three RECs would foster cooperation. However it is not clear who is the business person mentioned in this context?

The tripartite FTA is a more realistic and attainable alternative for Africa. ${ }^{11}$ It falls within the broader agenda of the African Constitutive Act derived from the Lagos Plan of Action of April 1980 that had long recognised these three RECs as building blocs for the grand African Economic Community (AEC). ${ }^{12}$ The Treaty of Abuja would gradually create an AEC within 34 to 40 years. ${ }^{13}$ Moreover, the tripartite solution will bring a much-needed solution to the multiple membership problems in the region. According to Francis Mangeni, Director of Trade, Customs and Monetary Affairs for COMESA:

\footnotetext{
"The Tripartite FTA would address multiple membership issues and it is aimed at creating a larger market to attract investors and enhance continental integration."
}

The tripartite FTA will harmonise one aspect of regional integration, which is trade. ${ }^{15}$ The tripartite FTA is also in line with the idea of the AU's African integration plan to facilitate trade across Africa and in this context SADC is the recognised REC for Southern Africa. ${ }^{16}$ This massive FTA will help resolve the spaghetti bowl conundrum of overlapping memberships of RECs in Southern and East Africa. ${ }^{17}$ This problem has not only retarded plans for individual RECs, but also the wider AEC envisaged for the African continent as a whole 
One of the main advantages of the proposed tripartite FTA is that trade agreements involving market access concessions may be negotiated more easily and more quickly than in multilateral agreements because fewer parties are at the table. This scenario will be in sharp contrast to the WTO situation where the Doha Round of trade negotiations has been slow as a result of many factors including the huge size of the forum. ${ }^{18}$ Thus, in the case of the tripartite FTA, parties can secure advantages that are harder to win in bigger forums.

Furthermore, an enlarged market for duty-free access is likely to increase trade creation as opposed to trade diversion. It is most likely that trade diversion will not occur since market access is not really a challenge for most countries currently enjoying preferential treatment for their goods in major markets. It is, however, likely that there will be gains from an increase in intra-industry trade, as trading partners trade goods that are currently produced in their own countries. ${ }^{19}$ With greater specialisation and efficiency, trade creation is the likely outcome, as the demand for goods produced regionally increases. ${ }^{20}$

The FTA will also be an opportunity to simplify the Rules of Origin requirements in the region, a challenge identified earlier in relation to the positions of South Africa and Egypt. Rules of Origin requirements often dilute the liberalising effect of FTAs and, if the Tripartite FTA can simplify these requirements, true liberalisation can be realised in the whole region. These hidden tariff-like measures would then no longer affect the price of domestically made inputs. ${ }^{21}$

Last but not least, the tripartite FTA elimination of non-tariff barriers is of critical importance. In the SADC region, as well as the other partners, the FTA comes as a result of decreased tariffs. This is not the case with NTB, which are always likely to increase. ${ }^{22}$ By their very nature, NTBs are any measures or interventions, other than tariffs, which distort or restrict trade in goods, services and factors of production.

\section{Challenges to the establishment of the tripartite FTA}

One of the major challenges that the tripartite FTA faces is its sheer membership size. Numbering 26 member states, potential pitfalls may arise and even reverse the progress already made in the individual RECs. Decision making may start to move at a snail's pace or even grinding to a halt. According to the neo-realist theory, given that member states are rational actors, and behave in self interested manners, and are influenced by domestic actors, getting to a consensus position at the supranational level may be painstakingly difficult. An experience from the EU of the 1965 Empty Chairs Crisis is a vivid reminder of how decision making can grind to a halt even in a supranational structure that comprises as few as six member states. Furthermore, the EU is also instructive in how increasingly difficult decision making has become as it widerns its membership. The challenge for the tripartite FTA will be on how to forge consensus on important substantive issues.

There is also a potential challenge of 'biting too much at once'. The huge membership number also brings a lot onto the table. The tripartite FTA will have to learn from the EU experience that regional integration is a process, not an event. In the neofunctionalist tradition, it is best to integrate the African economy, one sector at a time, and gradually via the construct of a new collective decision making centre. 
Many African countries have for decades enthusiastically embraced regional integration in a rather superficial manner. ${ }^{23}$ They sign agreements or treaties with alacrity, but are much less enthusiastic about implementation of their commitments. ${ }^{24}$ It will be interesting to observe whether the new tripartite FTA will be seen as a robust rules-based regimes. The challenge of the lack of rules-based mechanisms in Africa is closely related to another important theme running through the current regional integration agenda, and that is sovereignty. Independent states exercise their sovereignty right when entering into an agreement with other independent states to establish a regional economic community (REC). Such an act has implications which cannot be escaped by invoking national laws as a defence. Not even a constitutional defence can be used as a defence. African states need to realise that international agreements may well delimit their policy space.

It has been observed that intra-SADC trade liberalisation has is proceeding slower than that of COMESA and EAC. The potential of conflict is therefore very high. COMESA and the EAC may accuse SADC of slowing their trade liberalisation down. Bringing the SADC FTA and certain SACU trade practices within the ambit of the tripartite FTA may prove challenging. Furthermore there is need for a strategy for an asymmetrical tariff liberalisation whereby the less developed countries negotiate a longer tariff liberalisation timeframe. This can further be complicated by the need to draw up criteria on who makes up the less and more developed from among the member states. In a bid to protect their competitive advantage, member states are expected to stretch their list of sensitive products and as a result a number of exclusions and quotas may dilute the effectiveness of liberalisation under the new FTA. In addition, there is need to determine what would be an appropriate tariff liberalisation approach. Practical examples can be drawn from the COMESA FTA where Kenya granted a dispensation to restrict trade in wheat flour and cane sugar by way of tariff rate quotas. Seychelles also granted a dispensation to exclude a limited number of products from duty free treatment. Sudan and Egypt have also a special arrangement that exempts few selected products from duty-free treatment on products imported from Egypt. However the adopted principles of tariff regimes suggest a conventional approach that allows for some measure of flexibility, special and differential treatment together with the consideration of sensitive products and quatas.

Rules of origin regimes are also likely to cause conflict. Even though they are no visible conflicts in the EAC regime, conflict is apparent in the COMESA regime where Egypt applies $45 \%$ value addition rule of origin as opposed to $35 \%$ by other countries. Zimbabwe also granted a dispensation which lowered the value-added threshold for conferring origin under the value added criterion form $35 \%$ to $25 \%$ for selected products. The rules of origin for SADC are problematic, especially those applicable to textiles and clothing.

The emergence of a few poles of industrialisation in the region may lead to polarisation of investment towards the larger and more diversified economies. For this reason, there may be a need to set up a regulated compensatory payment system like the one currently operating within the SACU common revenue pool. ${ }^{25}$ This will be a big challenge if the SACU experience is considered. Currently, South Africa is not happy with the burden of funding the weak economies of SACU countries like Lesotho and Swaziland. ${ }^{26}$ According to Servaas van den Bosch: ${ }^{27}$ 


\begin{abstract}
"Plummeting revenues from the Southern African Customs Union (SACU) could cause severe financial difficulties in the region, economic experts warn. To make matters worse, the organisation is split over the future of its tariff pool that largely bankrolls the national budgets of its poorer members."
\end{abstract}

Customs revenue losses are expected in the tripartite Member States and this will be unwelcome news for many governments that depend on the revenue for the national budget. The SACU experience is equally relevant here: in 2009, the Namibian government obtained a staggering $39 \%$ of its fiscal income from SACU revenue. ${ }^{28}$ Lesotho and Swaziland derive more than half (in some years up to 70\%) of their national budgets from the customs union, while Botswana's derive 29\% from SACU revenue, according to its central bank. Only South Africa is less dependent on the union, as it receives a residual payout after all other member countries have received their share. ${ }^{29}$ This scenario is likely to play itself out in the proposed tripartite FTA and the effects will be exacerbated, since there are poorer countries in the proposed combined FTA. A solution could be trade reforms which will have to be accompanied by appropriate fiscal revenue policies to compensate for this loss of revenue. The legal implications flowing from this are that such policies will have to be negotiated into the tripartite FTA treaty.

Short-term losses resulting from the larger FTA could also include output and employment loses, as the removal of tariffs under the FTA will have different effects on sectors, sub-sectors and firms in each country. ${ }^{30}$ The effects of this kind of situation are already being felt in SADC and SACU, where South Africa benefits from employment losses of the region.

It is also not clear how the tripartite FTA is going to finance its activities. The three RECs finances have always been relying on donor funding. Such funding has been on the steep decline as a result of the economic downturn. Many member states have fallen behind their annual membership fees contributions within their respective RECs. If this state of affairs is allowed within the tripartite FTA, integration programmes are going to be seriously compromised. In SADC, the failure to pay membership fees has been attributed to individual member states economic development levels. This has prompted a discussion for member states to make contributions that are proportionate to their GDP. In SADC this will see South Africa contribute at least $20 \%$ of SADC's annual budget. It is not clear whether the tripartite FTA will take the same view.

The final and decisive challenge to this tripartite FTA is the political dimension of how the application of the tripartite FTA is undertaken. There are political tensions in some members of the proposed wider FTA. In SADC alone the political situation in the DRC, Madagascar and Zimbabwe has not been resolved. In the EAC, the situation concerning the new members, Rwanda and Burundi, is also unclear and requires definition. COMESA holds the highest of membership, with similar political problems in some of its Member States. On a political level, member states are likely to face the problem of scrambling for positions of influence in the new tripartite FTA. SADC member states will have to negotiate a Tripartite Agreement within the mandate of the SADC Treaty and SADC Protocol on Trade; otherwise the activity of joining the Tripartite FTA will conflict with SADC legal instruments. 


\section{Recommendations}

There is need to legitimise the tripartite FTA by creating a legal framework for its adoption in the three RECs. The initial formalisation of the legal framework has been undertaken by the June 2011 launch of the tripartite FTA negotiations. ${ }^{31}$ The new FTA also needs legal recognition from the $\mathrm{AU}$ and other international treaty bodies like the WTO and the UN. The AU has a specific Protocol on the Relations between the AU and the RECs. The WTO also requires notification of any RTA established under the provisions of Article XXIV. If successful, the tripartite FTA will definitely lead to deeper integration as envisaged in SADC and the whole continent of Africa. On the challenge of the polarisation of investment towards the larger and more diversified economies, a viable solution is to create a hub-and-spoke scenario. South Africa in the South, Kenya in the East and Egypt in the North become the hubs that are systematically linked to the rest of the other member states as spokes in the grand FTA. ${ }^{32}$ The key challenge that needs to be addressed is overcoming the reluctance by member states to implement the SADC FTA, a situation that may play itself out again in the tripartite FTA.

In trying to address these key issues, the tripartite FTA has to expedite the creation of certain supranational institutions, most notably a court or tribunal. This is critically important for the adjudication of disputes and interpretation of the legal provisions of the tripartite FTA. These supranational institutions will play a key role of neutralising the powerful effects of the Assembly of Heads of State and Government that command excessive influence from their respective RECs. This court or tribunal has to be empowered and be able to adjudicate cases that could well involve changing the traditional ways of doing business before the dawn of the tripartite FTA. There has been the absence of separation of powers in the individual RECs.

\section{Conclusions}

Regional integration on the continent of Africa remains a complex endeavour. Regional integration is a potential panacea for Africa's deplorable condition. ${ }^{33}$ The tripartite FTA has the potential to end some of the historical challenges like multiple memberships, the low intra-regional trade and the lack of rules-based trade. A positive environment can be created by a number of countries in the tripartite FTA who are interested in deeper economic integration. The need to address the poor regional infrastructure is high on the agenda of the tripartite FTA. It is imperative to realise that the signing of the tripartite FTA agreement will deliver nothing unless it is effectively implemented. Regional integration in three RECs involved needs fresh commitment and effective political will to deliver economic, social and political benefits for the people of the African continent. This Tripartite FTA framework can inspire other arrangements in Africa, and eventually be part of the broader framework of economic integration as envisaged by the Abuja Treaty and also the AU Constitutive Act.

\section{Notes}

1 Chauvin, S. and Gaulier, G. (2002) Regional Integration in Southern Africa [online] http://www.cepii.fr/anglaisgraph/workpap/pdf/2002/wp02-12pdf (accessed 20 September 2012). 
2 Mutharika, B. (1972) Towards Multinational Economic Cooperation in Africa, Praeger, New York.

3 Kalenga, P. (2011) SADC Annual Conference, 7-9 September, Cape Town [online] http://www.tralac.org (accessed 10 October 2012).

4 Ibid.

5 Lui, D. (2008) The Aid for Trade Agenda and Accompanying Measures for EPAs: Current State of Affairs, ECDPM Discussion Paper 86 Maastricht [online] http://www.ecdpm.org/Web_ECDPM/Web/Content/Navigation.nsf/index2?readformAE?Ope n document (accessed 20 November 2012).

6 Ibid.

7 Fundira, T. (2010) Regional Integration, Discussion on Proposed Tripartite FTA [online] http://www.tralac.org/cgi (accessed 13 October 2012).

8 The Official Communique [online] http://www.africa-eu.org./file/COMESA-EAC-SADC EN_221008.pdf (accessed 20 November 2012).

9 Ibid.

10 See COMESA official website (2008) COMESA-EAC-SADC leaders launch negotiations for the establishment of a Tripartite Free Trade Area [online] http://www.comesa.int/langen/component/content/article/707-comesa-eac-sadc-leaders-launch-negotiations-for-theestablishment-of-a-tripartite-free-trade-area (accessed 25 July 2012). See also Regional Trade Facilitation Programme [online] http://www.rtfp.org/eac.php (accessed 13 October 2012).

11 Ibid.

12 See Babarinde, O. (2007) The EU as a Model for the African Union: the Limits of Imitation, April, Vol. 7, No. 2, Jean Monnet/Robert Schuman Paper Series.

13 See [online] http://www.iss.co.za/AF/RegOrg/unity to_union/pdf/oau/treaties/AEC_Treaty_1991.pdf (accessed 20 November 2012).

14 Chikololere, P. (2010) 'Comesa moves towards tripartite FTA', The Standard, 8 May [online] http://allafrica.com/stories/201005101217.html (accessed 11 October 2012).

15 Shilimela, R. (2006) 'Monitoring Economic Integration in SADC 2006/2007: Overlapping Memberships of Regional Economic Arrangements and EPA Configurations in Southern Africa [online] http://www.foprisa.net/documents/monitoringSADC2006-7pdf (accessed 18 November 2012).

16 Ibid.

17 Gathii, J.T. (2009) African Regional Trade Agreements as Flexible Legal Regimes, Working paper series No. 2, Albany Law School, Albarney, New York.

18 Dube, M. (2012) The Way Forward for the WTO: Reforming the Decision-Making Process, Occasional Paper No. 118, Economic Diplomacy Programme.

19 Fundira (note 7 above); see also Petersson, L. (2003) 'Production fragmentation and specialisation with specific reference to SADC textile and clothing industry', South Africa Journal of Economics, p.71.

20 Ibid.

21 See generally Krishna, K. (2005) Understanding Rules of Origin [online] http://elsa.berkeley.edu/obstfeld/281sp04/Krishna survey3.pdf (accessed 13 October 2012).

22 Shilimela (note 15 above) 324.

23 Bosl, A. et al. (2010) Monitoring Regional Integration in Southern Africa Yearbook.

24 Ibid.

25 Mongardini, J., Benicio, D. and Thomson, F. (2011) In the Wake of the Global Economic Crisis: Adjusting to Lower Revenue of the Southern African Customs Union in Botswana, 
Lesotho, Namibia, and Swaziland IMF paper [online] http://www.imf.org/external/pubs/ft/dp/2011/afr1101.pdf (accessed 25 July 2012).

26 Lute, A. (2009) Future of SACU in doubt, South Africa Threatens to Pull Out, The Botswana Gazette, 9 June [online] http://www.gazettebw.com/index.php?option=com content\&view=article\&id=3334:future-ofsacu-in-doubt\&catid=18:headlines (accessed on 13 October 2012), see also, Shongwe, F. (2010) 'SACU revenue sharing formula to be finalised by year end', Times of Swaziland, 16 September [online] http://www.times.co.sz/index.php?news=20791 (accessed 13 October 2012).

27 See IPS (xxxx) Unexpected Low Level Customs Revenue Causes Budget Shortfalls [online] $\mathrm{http}: / /$ ipsnews.net/news.asp?idnews=50700 (accessed 13 October 2012).

28 Ibid.

29 Ibid.

30 Fundira (note 7 above).

31 See (note 9 above).

32 Githinji, P. (2010) EAC, COMESA, SADC Free Trade Area in the Offing, 13 July, The Standard online edition, Nairobi, Kenya.

33 See Babarinde (note 12 above). 